\title{
The Practices and Challenges of Internal School Supervision: The Case in East Wollega Secondary Schools
}

\author{
Tadesse Regassa Mamo ${ }^{1} \&$ Getahun Nigussa ${ }^{2}$ \\ ${ }^{1 \& 2}$ Department of Educational Planning and Management, Jimma University, Ethiopia \\ Correspondence: Tadesse Regassa Mamo, Jimma University, Ethiopia. \\ Email: tadesse.regassa@ju.edu.et
}

Received: January 7, 2019

Accepted: February 21, 2019

Online Published: March 1, 2019

doi: 10.23918/ijsses.v5i3p178

\begin{abstract}
The main objectives of this study was to look in to the practices, challenges and prospective of internal school supervision in secondary schools of East Wollega Zone. A descriptive survey research method was used to enable to assess the practices without any intervention. A multistage sampling technique was employed as selection of respondents was made at three stages. From all of the Woredas Secondary Schools, a total of ten (10) secondary schools were selected by availability sampling. Then from each ten (10) sample schools 64(100\%) education leaders (10 school principals, 10 deputy school principals, 4 secondary school supervisors and forty (40) department head teachers) were selected by available sampling techniques. Questionnaire, interview and document analysis were used as data gathering instruments. In addition, the researcher consulted relevant reference books; internet sources and supervision manuals to support the findings of the study and document analysis. Data was using mean score and $t$-test whereby the qualitative data was narrated to triangulate the qualitative data. The finding of the study revealed that internal supervisors were not doing what they have to do as they are overloaded by teaching assignment. Moreover, they were not doing the work of school community relation as they were having no time to liaison between school and community. On top of these the finding also revealed that the major challenges for internal supervisors were: teaching burden on supervisors, internal supervisors were few in number, lack of instructional support skills on supervisor side, attitude of both supervisors and supervises as well as less attention given to school based supervision. Therefore, it can be said the actual practices of school based supervision was not as per the intension. Hence, the education offices at various levels need to give due attention for enhance the skills of internal supervisors through rigorous pre- and in-service training program. It is also better to reduce the teaching load of internal supervisors so that they can get time to support teachers in the classroom as per the intention to have school based supervision.
\end{abstract}

Keyword: Supervision, Supervisory Practices, Internal Supervisors, Instructional Supervisors, Teacher Support, Training, Teacher Workload

\section{The Problem and Its Approach}

Supervisors should ensure that teachers are utilizing information from a variety of valid and appropriate sources before they begin planning and teaching lessons. Teachers should use different techniques of teaching methodology considering students background, academic levels, and interests, as well as other data from student's records to a certain academic needs and to facilitate planning for appropriate initial learning. The overall education system should be supported by educational supervision in order to improve the teaching-learning process in general and learner's achievement in particular (UNESCO, 2007). 
Working for students' progress towards the established standards and facilitate the planning of various types of instruction are the main tasks of internal supervisors. Internal supervision plays a crucial role in achieving the overall objectives and goals of education in the strategy of attaining quality education, focuses on teacher's professional growth to enhance the instructional practice in schools and to bring about the desired change of learning achievement for the students. In line with this, UNESCO (1999) indicated that internal supervisory practices are significant for individual teacher's professional development, school improvement and satisfaction of public demands. To this end, internal supervision should be well planned and organized to accommodate the central interest of teachers, students and the society. According to the view of Goble and Porter (1977), internal supervision is vital for the continuous professional development of teachers and the overall enhancement of quality education.

To make internal supervision more effective, collaboration should be made among various groups. As illustrated by the MOE (1994), the school principals, vice principals, department heads, and senior teachers should take major responsibility in internal supervisory practices within their school. These responsible partners involve themselves in the regular observation of teachers, and the organizing of short-term training and experience sharing to maximize the professional competence of teachers, and thus contribute for the quality of education. At Regional, Zonal and Woreda level in community mobilization documents, seminars, workshops (2011) and Woredas annual reports (2014) at East Wollega Zone repeatedly indicated that, in secondary school internal supervisors are not performing as it is expected.

In light with this, the researcher look in to the gaps that affects the improvement of quality education on the side of internal supervision practices as; education officers and principals did not exert much effort for the success of instructional improvement of teachers with the help of internal supervisors; internal supervisors did not design various interventions to assist teachers improve their limitations; internal supervisors did not provide professional support to teachers to improve their instructional skills; internal supervisors did not conduct training need assessment from the basis of teachers' pedagogical gaps; beginner teachers did not use student cantered /Active learning/ teaching methodology rather simply use lecture methods and internal supervisors did not link the schools with the school communities and other stakeholders to solve and to get financial problems.

In addition to this, the researcher look in detail of the challenges faced on internal supervisors; like that of overburdened by other works and did not get support from woreda education officers. So, relentless efforts were being made to alleviate the listed problems for the success of internal supervision. Besides, from the eighteen years Personal teaching, head teacher, cluster supervisor and secondary supervisors' experience of the researcher, a large number of secondary school internal supervisors seemed to not devote most of their time on systematic identifications of teachers' skill gap and support of teachers on their instructional activities. Besides, the current initiation for quality of education further rationalized the researcher to deal in the area under discussion, as supervision was a quality monitoring tool.

The researcher understood that there was a gap between what was demanded and what the internal supervisors were really doing. In addition to this, as to the knowledge of the researcher, particularly in the study area, there was no obviously adequate research conducted on the practices and challenges of internal supervision that is why the researcher was interested to study this topic. Due to this reason, the 
researcher felt that there was a gap which needs in depth investigation about the status of the current supervisory practices such as proper implementation of supervisory options and classroom observation, the proper implementation of internal supervisors' responsibilities.In doing so, the researcher raised the following basic research questions:

- What are the practices of internal school supervision in East Wollega Zone secondary schools?

- How far the intention and practices of internal school supervision linked?

- How far internal school supervisors link schools with school community groups to assure quality of education?

- What are the major challenges that affect the implementation of internal school supervision services?

\subsection{Objectives of the Study}

Specifically, the study was attempted:

- $\quad$ To assess the status of the implementation of internal school supervision practices

- $\quad$ To explore the link between the intentions and practices of internal supervision

- To assess the linkages between the school and the community

- $\quad$ To identify the major challenges hampering the practices of internal school supervision

\subsection{The Scope of the Study}

Since there are large number of schools (42 schools in the Zone), it was unrealistic and impractical to attempt to cover all the schools on the practice and challenges of internal school supervision. Therefore, the study was delimited to $10(24 \%)$ governmental secondary schools, $134(10 \%)$ teachers, 64(100\%) educational supervisors, (40 (100\%) department head, 10(24\%) school principals, 10(24\%) deputy principals), (4(24\%) secondary school Supervisors), 1(100\%) ZEO supervision expert, 4(24\%) WEO Supervision Experts, and also, the study were delimited to 4 (24\%) Woredas of East Wollega Zone. These are Wama Hagalo, Wayu Tuka, Nunnu kumba and Ebantu Woredas were selected. The study also, conceptually delimited to assess, the practice and challenges of supervisors to point out instructional limitations /gaps of the teachers/ by identifying their strength, the various interventions designed by supervisors so as to assist teachers reduce their teaching profession.

\section{The Research Design and Methodology}

\subsection{The Research Design}

The research design was the plan of action that links the philosophical assumptions to specific methods (Creswell \& Planoclark, 2007). The research design used for this study was descriptive survey design. This design helped the researcher to describe the current situation regarding practice of internal school supervision in the school. It also helped to draw valid general conclusions.

In this study, the research methods used both quantitative and qualitative approaches with more focus on quantitative one. Quantitative research consists of research in which the data can be analyzed in terms of numbers. Research can also be qualitative; that is, it can describe events and persons scientifically without the use of numerical data. A survey, according to Kothari (2004), is a method of securing 
information concerning an existing phenomenon from all or selected number of respondents of the concerned universe. The qualitative approach was incorporated in the study to validate and triangulate the quantitative data.

\subsection{Participants of the Study}

There were 42 governmental secondary schools organized under four clusters. Hence, the participants of this study were Zonal supervision expert, Woreda education offices supervision expert, educational leaders (secondary school supervisors, Principals, deputy-principals, department heads) and teachers were the participants of the study. This group of participants was appropriate for this study, because, they were among front line for internal school supervision and help the researcher to get reliable and first hand information about the issue in focus. Data for this research was collected from both primary and secondary sources. The primary sources of data were secondary school educational leaders, secondary school teachers, ZEO and WEO supervision experts. The secondary sources were school internal supervision recorded documents, action researches, feedbacks, supervision books and reports are the main source of data.

\subsection{Sample Size and Sampling Techniques}

Sample selection was done at three levels (Multi-stage sampling technique): Woredas, schools and individuals. The researcher favours this technique as it helps to get more representative sample from geographically scattered participants. According to Levy, Yalew Endawok and Limshow among the total population 10-30\% can fulfil the sample sizes. Currently there were a total of forty two (42) government secondary schools in the Zone. Since the number of the secondary schools is too large, grouping the woredas in to 4 clusters according to geographical location, then in each clusters 1 woredas was selected by simple random sampling technique. Because of their geographical scattered location and easily manage the sample populations.

In East Wollega Zone there are 17 Woredas, each Woreda was grouped in to four (4) clusters according to political strategy of the current government regarding geographical location. Thus, Gidda Ayana, Jimma Arjo, Nakemte and Sibu Sire clusters. And from each cluster four 4(24\%) Woredas (Wama Hagalo, Wayu Tuka, Nunnu kumba and Ebantu) were selected by simple random sampling. From all of the Woredas secondary Schools, a total of ten (10) secondary schools were selected by availability sampling. Then from each ten (10) sample schools 64(100\%) education leaders (10 school principals, 10 deputy school principals, 4 secondary school supervisors and forty (40) department head teachers) were selected by available sampling techniques. Because they were very important source of data for this study, their number was easily manageable. Four (4) WEO Supervision experts and One (1) ZEO supervision experts were taken as a sample of the study based on available sampling techniques. Because they are close to assist every schools activity so that they provide relevant and adequate information. To determine the sample size of teachers, for each school of selected secondary schools, the following stratified formula of William (1977) was utilized.

$\mathrm{nd}=\underline{\mathrm{Ndn}} \quad$ where $\mathrm{nd}=$ simple size of school $\mathrm{d}$.

$\mathrm{N} \quad \mathrm{Nd}=$ population of school $\mathrm{d}$. 


$$
\begin{aligned}
& \mathrm{n}=\text { total sample size of selected school teachers (for this study134) } \\
& \mathrm{N}=\text { total population of selected school (for this study was 268) }
\end{aligned}
$$

The aim of the calculation is to determine an adequate sample size to estimate the population prevalence with a good precision. Based on the calculation of the above mathematical formula, the total sample size of teachers for this study was 134. Accordingly, 32 teachers from Wama Hagalo (Mote 15, Kasso 11, Bata Wenni 6), 26 from Wayu Tuka (Gute 15, Burka Jimata 11), 32 from Nunnu kumba (Nunnu 21, Adare 11) and finally 44 from Ebantu (Hinde 22, Birbirsa Wajo 11, Qello 11) woreda secondary schools were selected. Finally, out of 268 teachers in the sample ten (10) secondary schools of East Wollega Zone, 50\% (134) of them was selected through stratified sampling technique. In addition, the researcher believes that the sample of $50 \%$ is sufficient to secure the validity of the data obtained from teacher respondents. The number of sampled teachers from each selected secondary schools determined by proportional number of teachers in each secondary school.

After determining the sample size from the total population, Simple random sampling technique (lottery method) was used based on teachers' proportion found in each sample school because this technique gives independent and equal chance to the participants to be selected in the samples. In addition, those groups were close supervision to everyday school activities of teachers and provide relevant information regarding the internal school supervision practice. Therefore the subjects of the study include 134 secondary school teachers, 64 educational leaders (10 principals, 10 vice principals, 40 department heads, 4 secondary school Supervisors) 4 WEO Supervision experts and 1 ZEO supervision experts.

\subsection{Data Gathering Instrument}

Questionnaire, interview and document analysis were used as data gathering instruments. In addition, the researcher consulted relevant reference books; internet sources and supervision manuals to support the findings of the study and document analysis. Questionnaire and interview were used as data gathering instruments. In addition, the researcher consulted relevant reference books; internet sources and supervision manuals to support the study and document analysis.

\subsubsection{Questionnaires}

Questionnaires were believed to be better to get greater amount of data from large number of respondents in a relatively shorter time with minimum cost. In this study, two sets of questionnaire items were used. The first set of items dealt with the general background of the respondents. The second set of questionnaires, which was prepared in English, was administered to teachers, internal supervisors and secondary school supervisors. In terms of content, the two set of questionnaires had 41 items. Likert scale was preferred because it enables the respondents to choose one opinion from the given scales that best aligns with their views (Koul, 1984). The scale consists of five scales, $5=$ strongly agree, $4=$ agree, 3 = undecided, 2 = disagree, and $1=$ strongly disagree.

\subsubsection{Interview}

Semi-structured interview was designed to gather data from 1 ZEO and 4 WEO supervision experts involved in interview process. The interview was conducted to obtain detailed information about the roles and contributions of instructional supervision. 


\section{Result and Discussion}

This part deals with the characteristics of the respondents, analysis and interpretation of data. The objective of this study was to assess the practices and challenges of internal school supervision of East Wollega Zone secondary Schools. To this end, both quantitative and qualitative data were gathered by using questionnaire, interview and document analysis.

\subsection{Characteristics of the Respondents}

As can be seen from the Table 1 item one, 101(75.37\%) from 134(100\%) of teachers and 58(90.62\%) from $64(100 \%)$ of educational leaders were males where the remaining 33(24.63\%), of teachers and $6(10 \%)$ of education leaders were females. The implication is that training females as both teaching and leading staff is demanding to curb the gender gap in the education system. Regarding work experience, the majority $55(41.05 \%)$ of teachers and 54(40.3\%) of school leaders were in between $11-15$ and between 6-10 years respectively while $14(10.45 \%)$ of teacher respondents had a 1-5 years of experience and $8(5.97 \%)$ of them had work experience between 16 and 20 years experience. Therefore, it can be implicated that most the teachers have adequate work experience to understand the reality in their schools concerning school based supervision.

Table 1: The Characteristics of the respondents

\begin{tabular}{|c|c|c|c|c|c|c|c|c|c|c|c|c|c|c|c|c|c|}
\hline $\mathrm{N}$ & \multirow{3}{*}{\multicolumn{4}{|c|}{ Items }} & & & & & & & & & & & & & \\
\hline 0 & & & \multicolumn{4}{|c|}{ Teachers $(n=134)$} & \multicolumn{4}{|c|}{ Total $(n=198)$} & & & & & & & \\
\hline & & & \multirow{2}{*}{\multicolumn{2}{|c|}{$\frac{\text { No }}{101}$}} & \multirow{2}{*}{\multicolumn{2}{|c|}{$\begin{array}{l}\text { No } \\
58\end{array}$}} & \multirow{2}{*}{\multicolumn{2}{|c|}{$\frac{\text { Nog }}{163}$}} & & & & & & & & & \\
\hline 1 & \multirow{3}{*}{\multicolumn{3}{|c|}{$\begin{array}{l}\text { Sex of } \\
\text { respondent }\end{array}$}} & & & & & & & & Male & & & & & & \\
\hline & & & & & & & & & & & Female & 33 & 24.63 & 6 & 9.38 & 35 & 17.68 \\
\hline & & & & & & & & & & & Total & 13 & 100 & 6 & 100 & 198 & 100 \\
\hline \multirow{7}{*}{\multicolumn{2}{|c|}{2}} & & & & & & & & & & $1-5$ years & 14 & 10.45 & - & - & 45 & 22.7 \\
\hline & & & & & & & & & & & $6-10 \mathrm{yrs}$ & 54 & 40.3 & 15 & 23.44 & 71 & 35.9 \\
\hline & & & & & & & & & & & $11-15 \mathrm{yrs}$ & 55 & 41.05 & 29 & 45.31 & 46 & 23.2 \\
\hline & & & & & & & & & & & $16-20 \mathrm{yrs}$ & 8 & 5.97 & 20 & 31.25 & 22 & 11.1 \\
\hline & & & & & & & & & & & $21-25 \mathrm{yrs}$ & 3 & 2.23 & - & - & 14 & 7.1 \\
\hline & & & & & & & & & & & $26-30 \mathrm{yrs}$ & - & - & - & - & - & \\
\hline & & & & & & & & & & & $\geq 31$ & - & - & - & - & - & \\
\hline \multirow{4}{*}{\multicolumn{2}{|c|}{3}} & & - & & & & & & & & Diploma & - & - & - & - & - & - \\
\hline & & & & & & & & & & & $\mathrm{BA} / \mathrm{BSc}$ & 13 & 98.5 & 6 & 100 & 198 & 100 \\
\hline & & & & & & & & & & & MA & 2 & 1.5 & - & - & & \\
\hline & & & 134 & & & & & & & & Total & 13 & 100 & 64 & 100 & 198 & 100 \\
\hline
\end{tabular}

(Source: Field Survey)

The remaining 3(2.23\%) of teachers had work experience of 21-25 years. In addition, 29(45.31\%) of educational leaders had work experience between 11 - 15 years. The remaining 20(31.25\%) and 15(23.44) educational leaders had work experience between 16 - 20 and 6-10 years respectively. 
Regarding the educational background of the respondents, the majority 32 (98.5\%) of teachers were first degree holder and the remaining 2(1.5\%) of teachers were MA holders while no one holds diploma. In case of educational leaders all of them, $64(100 \%)$ were first degree holders. From this, it is possible to conclude that all respondents in the sample Woredas had the same qualification.

\subsection{Extent of Support to Teachers from Internal Supervisors}

Item 1 of Table 2 was about the arrangement of induction training for beginner teachers and result revealed that internal school supervisors insufficiently arranged induction training for beginner teachers with mean score of $(\overline{\mathrm{X}}=2.403, \mathrm{SD}=0.989)$ and $(\overline{\mathrm{X}}=2.453, \mathrm{SD}=1.082)$ respectively. The t-test result showed that the significance level was found to be weak and no difference between teachers and leaders $\mathrm{t}(27)=-.477,(\mathrm{p}>0.05)$. Furthermore, from the interview with the WEO and ZEO supervision experts it was found that supervisors were not arranging induction training for instructional improvement for beginner teachers. The reason mentioned for this was the lack of knowledge and skills of how to arrange induction training. 
Table 2: Respondents view on interventions of internal supervisors to assist teachers

\begin{tabular}{|c|c|c|c|c|c|c|c|c|}
\hline \multirow[t]{2}{*}{ № } & \multirow[b]{2}{*}{ Item } & \multirow[t]{2}{*}{ Response } & \multicolumn{2}{|c|}{ Position } & \multirow{2}{*}{$\begin{array}{l}\text { Over } \\
\text { all } \\
\text { mean }\end{array}$} & \multicolumn{3}{|c|}{ T test } \\
\hline & & & $\begin{array}{l}\text { Teacher } \\
n=134\end{array}$ & $\begin{array}{l}\text { Educati } \\
\text { onal } \\
\text { leader } \\
\mathrm{n}=64\end{array}$ & & df & $\begin{array}{l}\mathrm{t}- \\
\text { value }\end{array}$ & $\begin{array}{l}\text { Sig( } \\
\text { p) }\end{array}$ \\
\hline \multirow[t]{3}{*}{1} & \multirow{3}{*}{$\begin{array}{l}\text { Instructional supervisors } \\
\text { arranging induction trainin } \\
\mathrm{g} \text { for beginner teachers }\end{array}$} & $\Sigma$ & 322 & 157 & \multirow[t]{3}{*}{2.428} & \multirow[t]{3}{*}{27} & \multirow[t]{3}{*}{-.477} & \multirow[t]{3}{*}{.097} \\
\hline & & $\overline{\mathrm{X}}$ & 2.403 & 2.453 & & & & \\
\hline & & S.D & 0.989 & 1.082 & & & & \\
\hline \multirow[t]{3}{*}{2} & \multirow{3}{*}{$\begin{array}{l}\text { Internal supervisors in the } \\
\text { school assist teachers in } \\
\text { lesson planning }\end{array}$} & $\Sigma$ & 312 & 159 & \multirow[t]{3}{*}{2.406} & \multirow[t]{3}{*}{27} & \multirow[t]{3}{*}{-.760} & \multirow[t]{3}{*}{.169} \\
\hline & & $\overline{\mathrm{X}}$ & 2.3284 & 2.484 & & & & \\
\hline & & S.D & 0.9793 & 1.0539 & & & & \\
\hline \multirow[t]{3}{*}{3} & \multirow{3}{*}{$\begin{array}{l}\text { Internal } \quad \text { supervisors } \\
\text { facilitate } \\
\text { sharing programs b/n } \\
\text { between teachers }\end{array}$} & $\Sigma$ & 320 & 154 & \multirow[t]{3}{*}{2.397} & \multirow[t]{3}{*}{27} & \multirow[t]{3}{*}{3.384} & \multirow[t]{3}{*}{.06} \\
\hline & & $\overline{\mathrm{X}}$ & 2.388 & 2.406 & & & & \\
\hline & & S.D & 0.964 & 1.164 & & & & \\
\hline \multirow[t]{3}{*}{4} & \multirow{3}{*}{$\begin{array}{l}\text { Internal supervisors assist } \\
\text { teachers in developing/sele } \\
\text { cting instructional materials }\end{array}$} & $\Sigma$ & 328 & 158 & \multirow[t]{3}{*}{2.455} & \multirow[t]{3}{*}{27} & \multirow[t]{3}{*}{.400} & \multirow[t]{3}{*}{.521} \\
\hline & & $\overline{\mathrm{X}}$ & 2.442 & 2.468 & & & & \\
\hline & & S.D & 0.992 & 1.167 & & & & \\
\hline \multirow[t]{3}{*}{5} & \multirow{3}{*}{$\begin{array}{l}\text { Internal supervisors spread } \\
\text { best practice teaching meth } \\
\text { odologies among school an } \\
\text { d teachers }\end{array}$} & $\Sigma$ & 325 & 147 & \multirow[t]{3}{*}{2.36} & 27 & -.965 & .84 \\
\hline & & $\overline{\mathrm{X}}$ & 2.425 & 2.296 & & & & \\
\hline & & S.D & 0.999 & 1.108 & & & & \\
\hline 6 & Internal supervisors & $\Sigma$ & 322 & 158 & 2.435 & 27 & .326 & .035 \\
\hline & facilitate professional & $\overline{\mathrm{X}}$ & 2.403 & 2.468 & & & & \\
\hline & $\begin{array}{l}\text { growth of teacher trough } \\
\text { short term training }\end{array}$ & S.D & 0.989 & 1.023 & & & & \\
\hline 7 & Internal supervisors & $\Sigma$ & 328 & 153 & 2.418 & 27 & -.273 & .594 \\
\hline & support teachers in doing & $\overline{\mathrm{X}}$ & 2.447 & 2.390 & & & & \\
\hline & action research & S.D & 1.0154 & 1.121 & & & & \\
\hline
\end{tabular}

NB: $*$ is a significant difference at $\alpha=0.05, \Sigma=$ Sum $=\bar{X}=$ mean score, S.D $=$ Standard Deviation (Source: Field Survey)

Item 2 of the table dealt with whether internal supervisors in the school assist teachers in lesson planning or not. Accordingly, teachers and education leaders with mean score of $(\overline{\mathrm{X}}=2.328, \mathrm{SD}=0.979)$ and $(\overline{\mathrm{X}}=$ $2.484, \mathrm{SD}=1.053$ ) respectively indicated that, internal school supervisors in the school failed to assist teachers in lesson planning as what was expected. The t-test result also revealed that the significance 
level $\mathrm{t}(27)=-.477, \mathrm{P}>0.05$. This indicated that there was no statistically significant difference of responses.

In the same table item 3 the result was low with mean score of $(\bar{X}=2.388, \mathrm{SD}=0.964)$ and $(\overline{\mathrm{X}}=2.406$, $\mathrm{SD}=1.164)$ respectively revealing internal supervisors were weak to facilitate experience sharing programs between teachers and leaders. The t-test revealed that the significance level $t(27)=-.384,(p>$ $0.05)$ and this indicated that there was no statistically significant difference of responses between the two group.

As shown on the same table item 4, the respondents were asked whether internal supervisors assist teachers in developing/selecting instructional materials or not. Accordingly, teachers and educational leaders with $(\overline{\mathrm{X}}=2.442, \mathrm{SD}=0.992)$ and $(\overline{\mathrm{X}}=2.468, \mathrm{SD}=1.167))$ mean scores respectively replied that, internal supervisors less assisted teachers in developing /selecting instructional materials. The qualitative data obtained from interview support this idea that, internal school supervisors do not assist teachers in developing /selecting instructional materials for teaching learning process. This is not in line with what was stipulated by MOE (2000):

"Teachers should develop and select instructional materials for proper teaching-learning process. This can improve teachers' performance of instruction and as the same time the students achieve and score high results because of these well oriented and well prepared teachers. Instructional skills, assessment skills, student management skills and subject matter knowledge can be improved when teachers develop/select instructional materials. As the same time students with different abilities to learn can be motivated and then try to grasp what they learn from the instructional materials".

In Table 2, item 5 was whether the internal supervisors share best practice on teaching methodologies among teachers and schools or not. Accordingly, teachers and educational leaders disagreed with mean scores $(\overline{\mathrm{X}}=2.425, \mathrm{SD}=0.997)$ and $(\overline{\mathrm{X}}=2.296, \mathrm{SD}=1.108)$ respectively indicating internal school supervisors inadequately spread best practice on teaching methodologies among teachers and schools to the required level. The t-test also depicted the absence statistically significance difference of responses $\mathrm{t}(27)=-0.965, \mathrm{p}>0.05)$ between teachers and leaders. Similarly, the interview made shown internal supervisors were not doing what they have to do to share best practice on teaching methodologies among teachers and schools.

In the same table item 6, the respondents were asked whether the internal school supervisors facilitate professional growth of teachers using various strategies and teachers and educational leaders with mean scores $(\overline{\mathrm{X}}=2.403, \mathrm{SD}=0.989)$ and $(\overline{\mathrm{X}}=2.468, \mathrm{SD}=1.023)$ respectively reported internal school supervisors were not facilitating professional growth of teachers through short term training, workshops and seminars. The t-test revealed that the significance level was $t(27)=-0.326, p>0.05$ revealing no statistically significance difference of responses in this regard between the two groups of respondents. Similarly, the interviewee addressed that the attempts made so far to build the professional capacity of teachers by internal supervisors was not meaningful.

Table 2 item 7 was whether the internal supervisors are supporting teachers in doing action research and develop supportive materials or not where teachers and educational leaders with mean score of $(\bar{X}$ $=2.447, \mathrm{SD}=1.015)$ and $(\overline{\mathrm{X}}=2.390, \mathrm{~S} . \mathrm{D}=1.121)$ respectively replied internal supervisors did not support 
teachers in doing action research and develop supportive materials. The t-test revealed that the significance level was $t(27)=-0.275, p>0.05$ showing there was no statistically significance difference of responses between teachers and school leaders. Similarly, one of the interviewee stated that:

“.....Internal supervisors inadequately support teachers in doing action research and supportive materials. Furthermore, the information obtained from the woreda and Zonal education officers through interview reveals that these activities are implemented on the department level, not on an individual teacher basis. In addition, the interview assured that internal supervisors are not capable enough to shoulder their responsibilities in assisting the day to day instructional activities of teachers in the schools. This is due to time constraints and large number of teachers in the schools".

This finding fits with Gashaw (2008) who identified one of the most embarrassing explanations for the current poor reputation of schools and the presumed failure of many excellent innovations is that teachers have not had adequate, well informed and direct supervision to help, understand and implement best practice. In general, the compiled result indicates that, internal school supervisors do not design various interventions so as to assist teachers improve their limitations. As a result the teachers had not got enough professional support to improve the day to day classroom instruction and instructional skills.

\subsection{The Major Challenges that Affect Internal Supervision}

In Table 3 of item 1, teachers and educational leaders with mean score of $(\overline{\mathrm{X}}=3.820, \mathrm{SD}=1.129)$ and $(\bar{X}=3.796, \mathrm{SD}=1.086)$ respectively confirmed that internal supervisors have no time to support teachers. The t-test analysis also revealed that internal supervisors were over burdened with many tasks with significance level of $\mathrm{t}(27)=-0.328, \quad \mathrm{p}>0.05$. Similarly during interview the participants indicated that internal supervisors were currently overburdened with many tasks. Therefore, almost all of the informants who participated in the interview express that having heavy work load is the major problem of internal supervision. One of the interviewee even said that:

“....Since most of our internal supervisors were having a teaching load more than 18 periods a week, it is impossible to provide internal supervision service to teachers. Besides, due to big workload of teachers the school forced to assign very small number of supervisors that are not adequate to provide supervisory service to all teachers." 
Table 3: Respondents View on major challenges of internal supervisors

\begin{tabular}{|c|c|c|c|c|c|c|c|c|}
\hline \multirow{2}{*}{$\begin{array}{l}\mathrm{N} \\
\underline{\mathrm{o}}\end{array}$} & \multirow[t]{2}{*}{ Item } & \multirow[t]{2}{*}{ Response } & \multicolumn{2}{|c|}{ Position } & \multirow{2}{*}{$\begin{array}{l}\text { Overall } \\
\text { mean }\end{array}$} & \multicolumn{3}{|c|}{$\mathrm{T}$ test } \\
\hline & & & $\begin{array}{l}\text { Teacher } \\
n=134\end{array}$ & $\begin{array}{l}\text { Educational } \\
\text { leader } n=64\end{array}$ & & Df & $\begin{array}{l}\mathrm{t}- \\
\text { value }\end{array}$ & $\operatorname{Sig}(p)$ \\
\hline \multirow[t]{3}{*}{1} & \multirow{3}{*}{$\begin{array}{l}\text { Instructional } \\
\text { supervisors are } \\
\text { overburdened } \\
\text { with many tasks }\end{array}$} & $\Sigma$ & 512 & 243.00 & \multirow[t]{3}{*}{3.808} & \multirow[t]{3}{*}{27} & \multirow[t]{3}{*}{-.328} & \multirow[t]{3}{*}{.745} \\
\hline & & $\overline{\mathrm{X}}$ & 3.8209 & 3.796 & & & & \\
\hline & & S.D & 1.1295 & 1.086 & & & & \\
\hline \multirow[t]{3}{*}{2} & \multirow{3}{*}{$\begin{array}{l}\text { Instructional } \\
\text { supervisors } \\
\text { teaches the } \\
\text { same credit like } \\
\text { ordinary teachers }\end{array}$} & $\Sigma$ & 505 & 236.00 & \multirow[t]{3}{*}{3.727} & \multirow[t]{3}{*}{27} & \multirow[t]{3}{*}{-1.10} & \multirow[t]{3}{*}{.278} \\
\hline & & $\overline{\mathrm{X}}$ & 3.7687 & 3.6875 & & & & \\
\hline & & S.D & 1.1497 & .97386 & & & & \\
\hline \multirow[t]{3}{*}{3} & \multirow{3}{*}{$\begin{array}{l}\text { Lack of adequate } \\
\text { training system }\end{array}$} & $\Sigma$ & 535 & 254.00 & \multirow[t]{3}{*}{3.980} & \multirow[t]{3}{*}{27} & \multirow[t]{3}{*}{-.637} & \multirow[t]{3}{*}{.529} \\
\hline & & $\overline{\mathrm{X}}$ & 3.9925 & 3.968 & & & & \\
\hline & & S.D & 0.96164 & 0.853 & & & & \\
\hline \multirow[t]{3}{*}{4} & \multirow{4}{*}{$\begin{array}{l}\text { Inadequate pre- } \\
\text { service and in } \\
\text { service training }\end{array}$} & $\Sigma$ & 529 & 241.00 & \multirow[t]{4}{*}{3.856} & \multirow[t]{4}{*}{27} & \multirow[t]{4}{*}{-.432} & \multirow[t]{4}{*}{.669} \\
\hline & & $\overline{\mathrm{X}}$ & 3.9478 & 3.7656 & & & & \\
\hline & & S.D & 1.02096 & 1.00384 & & & & \\
\hline & & & & & & & & \\
\hline
\end{tabular}

(Source: Field Survey)

Teachers and educational leaders with mean scores and standard deviation $(\overline{\mathrm{X}}=3.768, \mathrm{SD}=1.149)$ and $(\bar{X}=3.687, S D=0.973)$ respectively agreed that internal supervisors teach the same credit like other ordinary teachers. The t-test revealed that the significance level is $t(27)=-1.10, p>0.05$. This indicates there is no statistically significant difference of responses. Furthermore, the result obtained from interview confirms that most internal school supervisors have more than 18 periods per week which proves the study by MoE (1994) which found heavy work load of internal school supervisors affects the practice of internal supervision where shortage of time hinders provision of adequate supervision and assigning enough supervisors. Therefore, from result obtained it is possible to suggest that, internal supervisor teaches the same credit like other teachers and hence they had no time to support teachers.

As the same table item 3, teachers and educational leaders with mean of $(\overline{\mathrm{X}}=3.992, \mathrm{SD}=0.961)$ and $(\overline{\mathrm{X}}$ $=3.968, \mathrm{SD}=0.853$ ) respectively agreed that internal supervisors lack adequate training. The $\mathrm{t}$-test revealed that the significance level was $\mathrm{t}(27)=-0.637, \mathrm{p}>0.05$ showing that there is no statistically significant difference of responses. The data obtained from interview depicted internal supervisors have no adequate training which is very important to support teachers. As the same table item 4, teachers and educational leaders with mean and standard deviation $(\overline{\mathrm{X}}=3.947, \mathrm{SD}=1.020)$ and $(\overline{\mathrm{X}}=3.765, \mathrm{SD}=1.003)$ respectively indicated the absence of pre-service and in-service training was a challenge to enhance 
internal supervision. This is contrary to the views of Carron and Degrauwe (1997) which stated advisers, supervisors and other such staff need regular training, but they seldom received it as shown in this study. The $\mathrm{t}$-test revealed that the significance level is $\mathrm{t}(27)=-0.432, \mathrm{p}>0.05$ which indicated that there was no statistically significant difference of responses between the two groups.

Table 4: Factors affecting the work of supervision

\begin{tabular}{|c|c|c|c|c|c|c|c|c|}
\hline \multirow[t]{3}{*}{1} & \multirow{3}{*}{$\begin{array}{l}\text { Supervisors attitude } \\
\text { towards supervision } \\
\text { work is weak }\end{array}$} & $\Sigma$ & 526 & 252.00 & \multirow[t]{3}{*}{3.931} & \multirow[t]{3}{*}{27} & \multirow[t]{3}{*}{-.473} & \multirow[t]{3}{*}{.640} \\
\hline & & $\overline{\mathrm{X}}$ & 3.925 & 3.937 & & & & \\
\hline & & S.D & 0.978 & 0.973 & & & & \\
\hline \multirow[t]{3}{*}{2} & \multirow{3}{*}{$\begin{array}{lr}\text { Ability to } & \text { conflict } \\
\text { resolution } & \text { and } \\
\text { performance } & \text { counseling } \\
\text { is strong } & \end{array}$} & $\Sigma$ & 531 & 251.00 & \multirow[t]{3}{*}{3.942} & \multirow[t]{3}{*}{27} & \multirow[t]{3}{*}{.101} & \multirow[t]{3}{*}{.920} \\
\hline & & $\overline{\mathrm{X}}$ & 3.9627 & 3.9219 & & & & \\
\hline & & S.D & 0.9451 & 0.87839 & & & & \\
\hline \multirow[t]{3}{*}{3} & \multirow{3}{*}{$\begin{array}{l}\text { In adequate attention } \\
\text { given to supervision } \\
\text { service }\end{array}$} & $\Sigma$ & 524 & 249 & \multirow[t]{3}{*}{3.913} & \multirow[t]{3}{*}{27} & \multirow[t]{3}{*}{-1.04} & \multirow[t]{3}{*}{.305} \\
\hline & & $\overline{\mathrm{X}}$ & 3.9104 & 3.890 & & & & \\
\hline & & S.D & 0.9376 & 0.944 & & & & \\
\hline \multirow[t]{3}{*}{4} & \multirow{3}{*}{$\begin{array}{l}\text { Lack of clear direction } \\
\text { from woredas } \\
\text { education office experts }\end{array}$} & $\Sigma$ & 515 & 250 & \multirow[t]{3}{*}{3.874} & \multirow[t]{3}{*}{27} & \multirow[t]{3}{*}{-.925} & \multirow[t]{3}{*}{.305} \\
\hline & & $\overline{\mathrm{X}}$ & 3.8433 & 3.906 & & & & \\
\hline & & S.D & 1.0175 & 0.867 & & & & \\
\hline \multirow[t]{3}{*}{5} & \multirow{3}{*}{$\begin{array}{l}\text { Lack of cooperative, } \\
\text { honest, friendly and } \\
\text { collegial relationship }\end{array}$} & $\Sigma$ & 518 & 248 & \multirow[t]{3}{*}{3.870} & \multirow[t]{3}{*}{27} & \multirow[t]{3}{*}{-.925} & \multirow[t]{3}{*}{.363} \\
\hline & & $\overline{\mathrm{X}}$ & 3.8657 & 3.875 & & & & \\
\hline & & S.D & 1.0605 & 0.899 & & & & \\
\hline
\end{tabular}

(Source: Field Survey)

Table 4 item 1 is about factors negatively affecting the performance of internal supervisors in secondary schools. All the teachers and educational leaders with mean and standard deviation $(\overline{\mathrm{X}}=3.925$, $\mathrm{SD}=0.0978),(\overline{\mathrm{X}}=3.937, \mathrm{SD}=0.973)$ respectively indicated that the attitude of supervisors towards supervision work was a challenge to internal supervision. The t-test result also revealed that the significance level is $\mathrm{t}(27)=-0.432, \mathrm{p}>0.05$. This indicated that there was no statistically significant difference between the respondents with negative attitude on internal supervision. Similarly, the interviewee agreed that the attitude of supervisors towards supervision work was a challenge to educational supervision.

In Table 4 item 2, all the teachers, internal school supervisors and secondary school supervisors with mean score and standard deviation of $(\overline{\mathrm{X}}=3.962, \mathrm{SD}=0.945)$ and $(\overline{\mathrm{X}}=3.921, \mathrm{SD}=0.878)$ respectively indicated that the ability of conflict resolution and counselling towards supervision work was a challenge to internal supervision. The $t$-test revealed that the significance level $t(27)=-0.473, p>0.05$. This indicated that there is no statistically significant difference of responses. Similarly, during interview the respondents reported that ability to resolve conflict and counselling towards supervision work was a challenge to internal supervision. 
Furthermore, Table 4, item 3, all the teachers and educational leaders with mean scores and standard deviation of $(\overline{\mathrm{X}}=3.910, \mathrm{SD}=0.937),(\overline{\mathrm{X}}=3.890, \mathrm{SD}=0.944)$ respectively revealed the in adequate attention given to supervision service was a challenge to internal supervisors. The t-test result was not significant where it is $\mathrm{t}(27)=-0.101, \mathrm{p}>0.05$ This indicated that there was no statistically significant difference of responses. Similarly, interview participants explained no adequate attention was given to supervision service and it was a challenge to internal supervision.

In item number 4 of Table 4 , teachers, internal school supervisors and secondary school supervisors with mean scores and standard deviation of $(\overline{\mathrm{X}}=3.843, \mathrm{SD}=1.017)$ and $(\overline{\mathrm{X}}=3.906 . \mathrm{SD}=0.867)$ respectively agreed that there was lack of clear direction from WEO supervision experts and this was a challenge to internal supervision. The t-test revealed that the significance level is $t(27)=-0.925, p>$ 0.05. This indicated that there was no statistically significant difference of responses between the two groups. Similarly, during interview the respondents disclosed that lacks of clear direction from WEO experts was one of the challenge to internal school supervision.

Regarding item 5 of Table 4, teachers and educational leaders replied with mean scores and standard deviation of $(\overline{\mathrm{X}}=3.865, \mathrm{SD}=1.060)$ and $(\overline{\mathrm{X}}=3.875, \mathrm{SD}=0.899)$ respectively, showing lack of cooperation, honesty, friendly and collegial relationship with and among teachers were identified as a major challenge to the internal school supervision. The t-test also revealed that the significance level is $\mathrm{t}(27)=-0.925, \mathrm{p}$ $>0.05$, showing there was no statistically significant difference of the responses of the two groups.

\section{Conclusions and Recommendations}

\subsection{Conclusions}

Based on the findings of the study, it can be concluded that the practices of internal supervision was not in a position to improve classroom instruction. In the same vein, teachers were not getting what they are expected to gain from their immediate supervisors. Moreover, the findings of the study showed that internal supervision practices were challenged by both teachers and schools related problems. Therefore, it can be concluded that both teachers and school principals have not clearly articulated the primary essence of internal school supervision. Hence, the school environment was instead of playing supportive role becomes a challenge to the development and implementation of school based supervision.

\subsection{Recommendations}

Therefore, in order for the internal supervision play the central roles of improving classroom instruction and school performance, teachers need to be convinced internal supervisors are there to build their skills by identifying weakness and strengths. It is also good to consider the workload of internal supervisors in a way they can get time to support teachers and work on improving their instruction. School principals need to do their best to liaise the relation between teachers and school based supervisors in a way teachers develop positive attitude towards supervisors and the supervision system in schools.

The school community need to internalize that internal supervision was meant to increase the school autonomy whereby schools can regularly monitor their teacher performance and student outcome and hence internal supervisors remain of crucial importance for continued improvement of education. As most of the challenges of school based supervision were school related principals need to take for 
granted that internal supervision influences what happen in the core business of the school i,e teaching and learning.

\section{Acknowledgement}

First of all, we would like thank Jimma University for supporting us in financing this research undertaking. There are also colleagues who deserves appreciation for their moral support and motivation while data collection and analysis. We are also indebted to our respondents; teachers, supervisors principals and vice-principals for they gave us all the required information for conducting the study.

\section{References}

Carron, G., De Grauwe, A., \& Govinda, R. (2001). Supervision and Support Services in Asia. Volume I: A Comparative Analysis Paris: UNESCO/International Institute for Educational Planning.

Creswell, J. W. (2006). Research design, quantitative and mixed approaches (2nd Ed): London, Sage Publication Inc.

Gashsw, D. (2008). Supervisory Practice of Cluster Primary School Supervisors Promoting Teachers Professional Competences in West Gojjam Administration Zone: Unpublished Masters of Arts Thesis, at AAU.

Goble, N., \& Porter, J. (1977). The changing role of the teacher. Paris: NFER Publishing Co. Ltd.

Kothari, C. R. (2004). Research methodology: Methods and techniques. (2nd revised Ed.). New Delhi: New Age International (P) Ltd.

Koul, L. (1984). Methodology of an educational research. India: Vikas Publishing.

Lilian, C. M. (2007). Perception of classroom supervision by secondary school teachers in the Harare region. Unpublished Masters of Arts thesis, Tshwane University of technology.

MOE (1994). The new education and training policy. Policy Document of the Ethiopia Ministry of Education, Addis Ababa University.

MOE (2010). Education Sector Development Program IV (ESDP IV): Program Action Plan, Federal Ministry of Education, and Addis Ababa.

UNESCO (1999). Quality education through school-based supervision and support. Retrieved from unesdoc.unesco.org/images/0011/001174/117472e

UNESCO (2006). Teachers and educational quality: Monitoring global needs for 2015. Montreal: Succursale Center-Ville.

UNESCO (2007). Reforming school supervision for quality improvement. Retrieved in 2006 from www.iiep.unesco.org/filedmin/.../Supervision/SUP_Mod8.pdf 